\title{
THE PRESENCE OF THYROID DYSFUNCTION IN NEWLY DETECTED METABOLIC SYNDROME PATIENTS
}

\author{
Alagianambi Shanmugam¹, Senathipathi Vengojayaprasad², Duraisamy Venkatesh ${ }^{3}$, Stephen Charles Bronson ${ }^{4}$, \\ Thayanithi Jayapackiam5, Duvuru Shantharam 6 \\ ${ }^{1}$ Associate Professor, Institute of Diabetology, Stanley Medical College, Chennai. \\ ${ }^{2}$ Associate Professor, Department of Diabetology, Coimbatore Medical College, Coimbatore. \\ ${ }^{3}$ Senior Resident, Department of Diabetology, Coimbatore Medical College, Coimbatore. \\ ${ }^{4}$ Senior Resident, Institute of Diabetology, Stanley Medical College, Chennai. \\ ${ }^{5}$ Assistant Professor, Institute of Diabetology, Stanley Medical College, Chennai. \\ ${ }^{6}$ Director and Professor, Institute of Diabetology, Stanley Medical College, Chennai.
}

\section{ABSTRACT}

\section{BACKGROUND}

The metabolic syndrome is also known as syndrome $\mathrm{X}$, the insulin resistance syndrome and the deadly quartet. The constellation of metabolic abnormalities includes insulin resistance, glucose intolerance, central obesity, dyslipidaemia and hypertension, as well documented risk factors for cardiovascular disease. When grouped together, they are associated with increased risk of cardiovascular disease. The concept of metabolic syndrome exists at least 80 years. That was first described in the 1920 s by Kelin, a Swedish physician as the clustering of hypertension, hyperglycaemia and gout. An overt hypothyroidism is associated with all the parameters of metabolic syndrome, except increase in fasting blood glucose.

The objectives of this study is to study the prevalence of thyroid dysfunction in the newly detected Metabolic Syndrome patients and to find out the correlation between the thyroid dysfunction and metabolic syndrome parameters.

\section{MATERIALS AND METHODS}

This is a cross-sectional study and it was conducted at Institute of Diabetology, Madras Medical College and Government General Hospital for a period of 8 months.

\section{RESULTS}

Total number of participants in this study was 60 in number. In this study group, $33(60 \%)$ were females and 27 (40\%) were males. On analysis of 60 people for the thyroid dysfunction, 8 were positive which represents $16.7 \%$ in percentage. Prevalence of hypothyroidism is $15.0 \%$ (overt hypothyroidism $3.3 \%$ and subclinical hypothyroidism $11.7 \%$ ) in metabolic syndrome patients. Only one study subject among the metabolic syndrome found to have subclinical hyperthyroidism (1.7\%). There were no overt hyperthyroidism patients in our study. Correlation coefficient values between FT4, TSH and metabolic parameters are not significant in our study.

\section{CONCLUSION}

One sixth of metabolic syndrome patients or every sixth metabolic syndrome had hypothyroidism either overt or subclinical. Exclude the presence of Thyroid dysfunction, while managing metabolic syndrome patients.

\section{KEYWORDS}

MS - Metabolic Syndrome, WC - Waist Circumference, SBP - Systolic Blood Pressure, DBP - Diastolic Blood Pressure, FBS - Fasting Blood Sugar, TC - Total Cholesterol, HDL-C - High Density Lipoprotein Cholesterol, TGL - Triglycerides, LDL-C - Low Density Lipoprotein Cholesterol, FT4 - Free Thyroxine 4, TSH - Thyroid Stimulating Hormone.

HOW TO CITE THIS ARTICLE: Shanmugam A, Vengojayaprasad S, Venkatesh D, et al. The presence of thyroid dysfunction in newly detected metabolic syndrome patients. J. Evolution Med. Dent. Sci. 2017;6(12):976-982, DOI: 10.14260/Jemds/2017/209

\section{BACKGROUND}

Metabolic Syndrome (MS) is a cluster of metabolic abnormalities wherein people are obese and have hypertension, high triglyceride level, low high density lipoprotein and abnormal fasting glucose levels. $(1,2)$ People

Financial or Other, Competing Interest: None.

Submission 30-12-2016, Peer Review 22-01-2017,

Acceptance 30-01-2017, Published 09-02-2017.

Corresponding Author:

Alagianambi Shanmugam,

Associate Professor,

Institute of Diabetology,

Government Stanley Medical College,

Chennai-01.

E-mail: drshanmugaa@gmail.com

DOI: $10.14260 /$ jemds $/ 2017 / 209$

(c) (i) $($ ) with metabolic syndrome are at high risk for developing cardiovascular disease.(3) Insulin resistance is supposed to be the central pathophysiological phenomenon underlying the clustering.(4)

Thyroid disease is associated with atherosclerotic cardiovascular disease. (5-8) This association may be in part be explained by thyroid hormone's regulation of lipid metabolism and its effect on blood pressure. Thyroid hormones have ubiquitous effects and influence the function of most organs. This hormone appears to serve as a general pacemaker accelerating metabolic process and may be associated with metabolic syndrome.(9)

Both metabolic syndrome and thyroid dysfunction are associated with increased risk of atherosclerotic heart disease. Little is known about the relationship between metabolic syndrome and thyroid dysfunction. Only a few small studies have been performed.(10,11) In a cross-sectional 
study in 220 metabolic syndrome patients, it was found that subclinical hypothyroidism was prevalent in $16.4 \%$ of metabolic syndrome patients.(10) In another study, it was found that metabolic syndrome was prevalent in thyroid dysfunction patients.(11) There is no information available in literature regarding this association in this part of the country. Therefore, the association of thyroid dysfunction with metabolic syndrome was evaluated in this study.

Although, Reaven GM already highlighted the concepts of insulin resistance and metabolic syndrome in 1988, it was not until 1998 before the first attempt for an internationally accepted definition was put forward.(12) Since then several expert groups have formulated and adapted definitions. (13-17) In an attempt to achieve some agreement on definition and to provide a tool for clinicians and researchers, a WHO consultation proposed a set of criteria. Subsequently, the National Cholesterol Education Program's Adult Treatment Panel (NCEP: ATP III) and the European Group for the Study of Insulin Resistance (EGIR) have formulated definitions. These definitions agree on essential components - glucose intolerance, obesity, hypertension and dyslipidaemia - but do differ in the detail and criteria.

\section{IDF 2005(17) Criteria for MS}

For a person to be defined as having the metabolic syndrome they must have:

Central Obesity - waist circumference $\geq 94 \mathrm{~cm}$ for Europid men and $\geq 80 \mathrm{~cm}$ for Europid women.

For South Asians - Waist circumference $\geq 90$ for men and $\geq$ 80 for women.(18)

\section{Plus any two of the following four Factors}

1. Raised TG level $\geq 150 \mathrm{mgs} / \mathrm{dL}$ or any specific treatment.

2. Reduced HDL cholesterol $<40 \mathrm{mg} / \mathrm{dL}$ in males and $<50$ $\mathrm{mg} / \mathrm{dL}$ in females.

3. Raised blood pressure $\geq 130 / 85 \mathrm{mmHg}$ or medication.

4. Raised fasting glucose $\geq 100 \mathrm{mg} / \mathrm{dL}$ or previously diagnosed type 2 diabetes.

A major issue for the IDF consensus consultation was the fact that criteria used for obesity in Asian and other populations could be different from those used in the west. This issue was supported by International Obesity Task Force.(19) They noted that in urban Asians, the body mass index range of 23 - 24 has an equivalent risk of type 2 diabetes, hypertension and dyslipidaemia as a body mass index of 25 - 29.9 in white people.

\section{Thyroid Function and the Metabolic Syndrome}

It is well documented that hypothyroidism is associated with all the parameters of metabolic syndrome, except increase in fasting blood glucose.

\section{Obesity}

The obesity (increase in waist circumference) is the important symptom and sign of hypothyroidism. More than $60 \%$ of hypothyroid patients have obesity (increase in waist circumference).(20) There is decrease in basal metabolic rate and energy metabolism in hypothyroidism.

\section{Hypertension}

In hypothyroidism, the haemodynamic alterations cause narrowing of pulse pressure, prolongation of circulation time and decrease in blood flow to the tissues. Systemic vascular resistance is increased in hypothyroidism and results in hypertension.(21) Rotterdam study(6) suggested that there was a two-fold increase in risk of atherosclerosis in hypothyroid patients.

\section{Lipid Profile}

Both the synthesis and degradation of lipid are depressed in hypothyroidism, the latter especially so, the net effect being one of the lipid accumulation, especially of low-density lipoprotein cholesterol and triglycerides. (22) The increase in serum cholesterol in hypothyroidism is accompanied by increased levels of serum phospholipids, serum triglycerides, and the low density lipoprotein cholesterol. The activity of cholesterol ester transfer protein is decreased in hypothyroidism, thus high density lipoprotein cholesterol level reduced in hypothyroidism.(23)

\section{Previous Related Studies}

On population based study found that even in euthyroid state, thyroid hormone assay is associated with components of the metabolic syndrome.(24) In this population based study, there was a negative correlation between thyroid hormone levels (free T4 and free T3) and metabolic syndrome components, Apo B and insulin resistance levels in people with euthyroid state. Free T4 was very significantly related to four of five metabolic syndrome components - waist circumference, fasting glucose, high density cholesterol and triglycerides and insulin resistance level, which assessed by the Homeostasis Model Assessment (HOMA) model, i.e. low normal free T4 was associated with higher triglycerides, lower high density lipoprotein cholesterol, increased fasting glucose and higher waist circumference. Free T3 levels correlated well with systolic blood pressure, triglycerides and Apo-B levels. In insulin resistance individuals are more susceptible to the association of TSH with higher low density lipoprotein cholesterol and lower high density lipoprotein cholesterol.(25) The morbid obese subjects have higher level of T3, T4 and TSH, probably of the reset of their central thyrostat at higher levels.(26)

In a study done by Uzunulu et al, at Japan, they have analysed the prevalence of sub-clinical hypothyroidism among 220 metabolic syndrome patients. They found that sub-clinical hypothyroidism was $16.4 \%$ prevalent in metabolic syndrome patients.(10) One sixth of metabolic syndrome patients had sub-clinical hypothyroidism and more prevalent in female gender.

In a study from Nepal, done by Chandra $\mathrm{L}$ et al, found that the metabolic syndrome prevalent in $21.1 \%$ of thyroid dysfunction patients.(11) They have assessed the association of metabolic syndrome and its components with thyroid dysfunction in 100 female patients. This study found that the prevalence of overall metabolic syndrome was $32 \%$, more in euthyroid group (21/48) than hyperthyroid group $(5 / 24)$ and hypothyroid group (6/28).(11) 


\section{MATERIALS AND METHODS}

\section{Setting}

The study was conducted on the outpatients attending the Institute of Internal Medicine and Institute of Diabetology, Madras Medical College and Government General Hospital, Chennai. Institutional Ethical Committee approved the study.

\section{Study Design}

Single Center, non-randomised cross-sectional study.

\section{Sample Size}

In the study period of 8 months among the patients attending the Institute of Diabetology, after applying inclusion and exclusion criteria 60 patients were included in this study.

\section{Selection of Study Subjects}

The patients who fulfilled the criteria for metabolic syndrome by IDF were taken into the study. For a person to be defined as having the metabolic syndrome they must have:

1. Central obesity - waist circumference $\geq 90 \mathrm{~cm}$ for men and $\geq 80 \mathrm{~cm}$ for women.

\section{Plus any two of the following Four Factors}

2. Raised TG level $\geq 150 \mathrm{mgs} / \mathrm{dL}$ or any specific treatment.

3. Reduced HDL cholesterol $<40 \mathrm{mg} / \mathrm{dL}$ in males and $<50$ $\mathrm{mg} / \mathrm{dL}$ in females.

4. Raised blood pressure $\geq 130 / 85 \mathrm{mmHg}$ or medication.

5. Raised fasting glucose $\geq 100 \mathrm{mg} / \mathrm{dL}$ or previously diagnosed type 2 diabetes.

\section{Inclusion Criteria}

Metabolic syndrome patients not on any medications - newly detected metabolic syndrome patients.

\section{Exclusion Criteria}

1. Known Hypothyroid/Sub-clinical Hypothyroid.

2. Taking medications for DM/SHT/Thyroid Disorder.

3. Taking steroids.

4. Severely ill patients.

5. Pregnant women.

6. Individuals below 18 yrs.

\section{Consent}

All participants gave written informed consent.

\section{Methodology}

Detailed history of medication and anthropometric measurements like height, weight and waist circumference were noted in a semi-structured proforma. Blood pressure was recorded in right upper limb in sitting posture. After eight hours of fasting, blood drawn for fasting blood sugar, lipid profile and thyroid assay in a single sitting.

The fasting blood sugar was done by enzymatic colorimetric method using semi autoanalyser. The highdensity lipoprotein cholesterol and triglycerides were done enzymatically on XL-300 ERBA fully automated clinical chemistry analyser. The thyroid hormone assay (TSH and FT4) were done by Chemiluminescence Immunoassay (CLIA) using ADVIA Centaur equipment.

\section{Definitions}

As per the joint statement from the American Association of Clinical Endocrinologists, the American Thyroid Association and The Endocrine Society.(27)
Euthyroidism is defined as

TSH $-0.4 \mathrm{mU} / \mathrm{L}$ to $4.5 \mathrm{mU} / \mathrm{L}$

FT4 - $0.70 \mathrm{ng} / \mathrm{dL}$ to $1.80 \mathrm{ng} / \mathrm{dL}$

Sub-Clinical Hypothyroidism

TSH $-4.51 \mathrm{mU} / \mathrm{L}$ to $10.0 \mathrm{mU} / \mathrm{L}$

FT4 $-0.70 \mathrm{ng} / \mathrm{dL}$ to $1.80 \mathrm{ng} / \mathrm{dL}$

Hypothyroidism

TSH - > $10.0 \mathrm{mU} / \mathrm{L}$

FT4 $-<0.70 \mathrm{ng} / \mathrm{dL}$

Sub-Clinical Hyperthyroidism

$\mathrm{TSH}-0.1 \mathrm{mU} / \mathrm{L}$ to $0.4 \mathrm{mU} / \mathrm{L}$

FT4 $-0.70 \mathrm{ng} / \mathrm{dL}$ to $1.80 \mathrm{ng} / \mathrm{dL}$

\section{Hyperthyroidism}

TSH $-<0.1 \mathrm{mU} / \mathrm{L}$

FT4 - > $1.80 \mathrm{ng} / \mathrm{dL}$

Statistical Analysis

SPSS 12 and Excel were used for data analysis.

\section{RESULTS}

\section{Population Characteristics}

Among the 60 patients included in our study, 27 patients were men accounting for $45 \%$ of the total cases. The remaining 33 patients were $(55 \%)$ women.

According to the age, patients between 30 and 39 years of age were 15 in number (25\%). Majority of the patients were in the age group between 40 and 49 years - 28 patients $(47 \%$ of study population) were in this group; 11 patients $(18 \%)$ were between the age of 50 and 59 years; 6 patients $(10 \%)$ were above the age of 60 . Population characteristics are shown in Table 1.

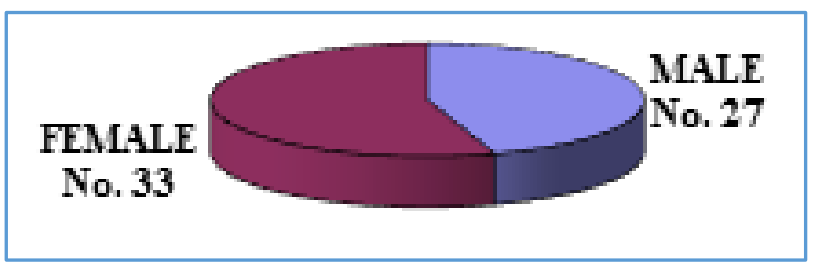

Figure 1. Sex Wise Population Characteristics

\begin{tabular}{|c|c|c|c|c|}
\hline Age & Total No. & Percentage & Male & Female \\
\hline $30-39$ & 15 & $25 \%$ & 6 & 9 \\
\hline $40-49$ & 28 & $47 \%$ & 14 & 14 \\
\hline $50-59$ & 11 & $18 \%$ & 1 & 10 \\
\hline $60-69$ & 6 & $10 \%$ & 6 & 0 \\
\hline \multicolumn{5}{|c|}{ Table 1. Population Characteristics } \\
\hline
\end{tabular}

According to the metabolic syndrome parameters, in the included 60 members in the study 19 fulfilled three among five metabolic syndrome parameters criteria. Another 19 members fulfilled four metabolic syndrome parameters criteria and the rest of 22 members fulfilled all the metabolic syndrome criteria.

\section{Thyroid Function Test Results}

The TSH in this study was ranging from $0.17 \mathrm{mU} / \mathrm{L}$ to 150 $\mathrm{mU} / \mathrm{L}$ and free $\mathrm{T} 4$ levels ranging from $0.16 \mathrm{ng} / \mathrm{dL}$ to 1.68 ng/dL. Patients were grouped into four groups according to the definitions based on TSH and FT4 levels and further statistical analysis was done based on these groups. 
According to our definitions, 50 patients found to be euthyroid and two patients were hypothyroid. Seven patients had sub-clinical hypothyroidism and one patient had subclinical hyperthyroidism. There were no overt hyperthyroid patients in our study.

\begin{tabular}{|c|c|c|c|c|}
\hline Group & No. & $\mathbf{\%}$ & Male & Female \\
\hline Euthyroid & 50 & $83.33 \%$ & 26 & 24 \\
\hline Hypothyroid & 2 & $3.33 \%$ & 1 & 1 \\
\hline Sub-clinical Hypothyroid & 7 & $11.67 \%$ & 0 & 7 \\
\hline Sub-clinical Hyperthyroid & 1 & $1.67 \%$ & 0 & 1 \\
\hline Hyperthyroidism & 0 & 0 & 0 & 0 \\
\hline \multicolumn{4}{|c|}{ Table 2. Thyroid Dysfunction } \\
\hline
\end{tabular}

The thyroid dysfunction is $16.7 \%$ prevalent in metabolic syndrome patients. Among the thyroid dysfunction, subclinical hypothyroidism is highly prevalent - $11.7 \%$. The hypothyroidism is $3.3 \%$ prevalent in metabolic syndrome patients (one patient had TSH levels of more than $150 \mathrm{mU} / \mathrm{L}$ ) and sub-clinical hyperthyroidism is $1.7 \%$ prevalent. There were no overt hyperthyroidism patients in our study.

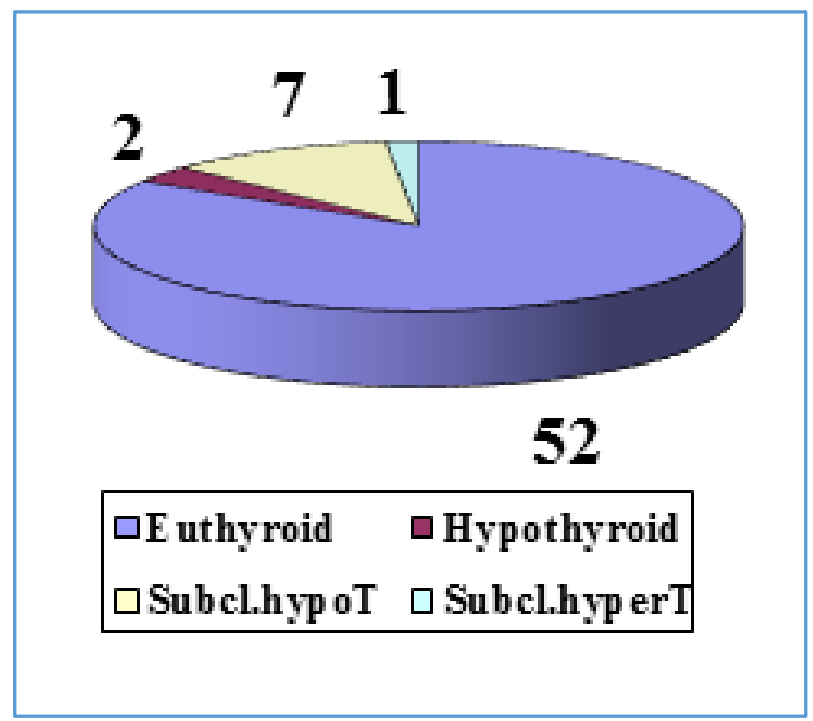

Figure 2. Thyroid Dysfunction

According to the age patient's age between 30 and 39 years were 15 in number, among them one patient had frank hypothyroidism and one patient had sub-clinical hypothyroidism. In the 40 - 49 age group, 4 patients had subclinical hypothyroidism and one patient had sub-clinical hyperthyroidism. In the 50 - 59 years' age group, one patient had frank hypothyroidism and two patients had sub-clinical hypothyroidism. In the above at the age of 60 , all 6 patients were normal.

\begin{tabular}{|c|c|c|c|c|c|}
\hline Age & $\begin{array}{c}\text { Total } \\
\text { No. }\end{array}$ & Euthyroid & $\begin{array}{c}\text { Hypo- } \\
\text { Thyroid }\end{array}$ & $\begin{array}{c}\text { Sub- } \\
\text { Clinical } \\
\text { Hypo- } \\
\text { thyroid }\end{array}$ & $\begin{array}{c}\text { Sub- } \\
\text { Clinical } \\
\text { Hyper- } \\
\text { thyroid }\end{array}$ \\
\hline $30-39$ & 15 & 13 & 1 & 1 & 0 \\
\hline $40-49$ & 28 & 23 & 0 & 4 & 1 \\
\hline $50-59$ & 11 & 8 & 1 & 2 & 0 \\
\hline $60-69$ & 6 & 6 & 0 & 0 & 0 \\
\hline \multicolumn{6}{|c|}{ Table 3. Age Wise Thyroid Dysfunction } \\
\hline
\end{tabular}

Based on the metabolic syndrome criteria, of those patients who fulfilled three of the five risk factors three had thyroid dysfunction; of the patients who had four risk factors, two had thyroid dysfunction; of the patients who had all five risk factors, five had thyroid dysfunction.

\begin{tabular}{|c|c|c|c|c|c|}
\hline $\begin{array}{c}\text { MS } \\
\text { Criteria } \\
\text { Fulfilled }\end{array}$ & $\begin{array}{c}\text { Total } \\
\text { No. }\end{array}$ & Euthyroid & $\begin{array}{c}\text { Sub- } \\
\text { Hypo- } \\
\text { Thyroid }\end{array}$ & $\begin{array}{c}\text { Sub- } \\
\text { Clinical } \\
\text { Hypo- } \\
\text { thyroid }\end{array}$ & $\begin{array}{c}\text { Clinical } \\
\text { Hyper- } \\
\text { thyroid }\end{array}$ \\
\hline 3 & 19 & 16 & 1 & 2 & 0 \\
\hline 4 & 19 & 17 & 0 & 1 & 1 \\
\hline 5 & 22 & 17 & 1 & 4 & 0 \\
\hline \multicolumn{6}{|c|}{ Table 4. Metabolic Syndrome Parameters Wise Thyroid } \\
Dysfunction \\
\hline
\end{tabular}

( $\mathrm{P}$ valve $=0.36$ not significant $)$

As there were a considerable number of patients only in both euthyroid group (50) and sub-clinical hypothyroid group (7), both groups were analysed statistically using student t-test. But these analyses were not statistically significant, as they were very small no. of individuals in both sub-groups and variants are very high in both sub-groups. Correlation between the FT4, TSH and metabolic parameters were also analysed.

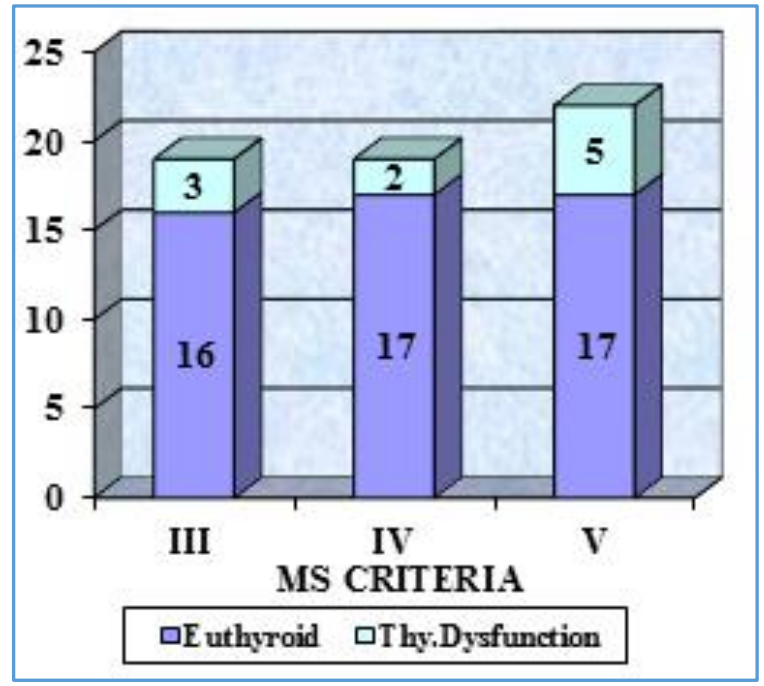

Figure 3. Metabolic Syndrome Parameters Wise Thyroid Dysfunction

\begin{tabular}{|c|c|c|c|c|c|}
\hline \multirow{2}{*}{$\begin{array}{c}\text { MS } \\
\text { Parameters }\end{array}$} & \multicolumn{2}{|c|}{ Euthyroid } & \multicolumn{2}{c|}{$\begin{array}{c}\text { Sub-Clinical } \\
\text { Hypothyroidism }\end{array}$} & \multirow{2}{*}{ P Value } \\
\cline { 2 - 5 } & Mean & SD & Mean & SD & \\
\hline WC & 97.16 & 6.98 & 98.57 & 8.32 & 0.626 \\
\hline SBP & 139.88 & 14.14 & 140.29 & 14.40 & 0.944 \\
\hline DBP & 89.52 & 7.28 & 88.29 & 9.20 & 0.689 \\
\hline FBS & 158.28 & 51.04 & 141.43 & 37.82 & 0.405 \\
\hline HDL & 43.46 & 6.25 & 43.43 & 4.58 & 0.990 \\
\hline TGL & 234.20 & 170.18 & 185.57 & 93.75 & 0.434 \\
\hline
\end{tabular}

(P valve $>0.05$ not significant at $5 \%$ level)

As there were small no. of patients with very high variants, statistically significant results were not found. 


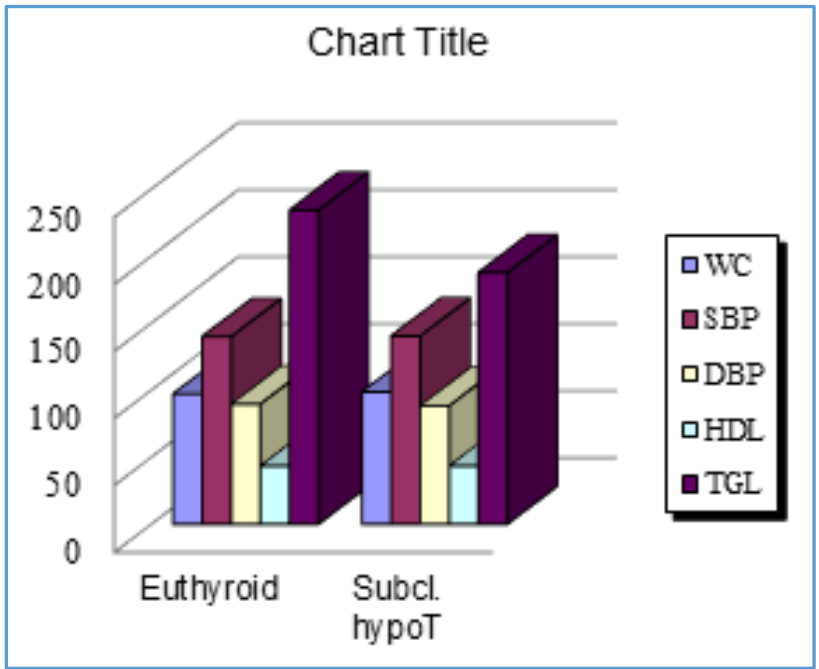

Figure 4. Distribution of Thyroid Dysfunction

\begin{tabular}{|c|c|c|c|c|}
\hline MS & FT4 & P Value & TSH & P Value \\
\hline WC & 0.243 & 0.08 & -0.029 & 0.839 \\
\hline SBP & 0.078 & 0.59 & 0.076 & 0.60 \\
\hline DBP & 0.125 & 0.38 & -0.416 & 0.77 \\
\hline FBS & 0.175 & 0.22 & -0.095 & 0.59 \\
\hline HDL & 0.067 & 0.64 & -0.108 & 0.45 \\
\hline TGL & 0.056 & 0.69 & -0.066 & 0.30 \\
\hline \multicolumn{5}{|c|}{ Table 6. Correlation between FT4, TSH and Metabolic } \\
\hline
\end{tabular}

( $\mathrm{P}$ valve $>0.05$ not significant at $5 \%$ level)

\begin{tabular}{|c|c|c|c|c|}
\hline MS & FT4 & P Value & TSH & P Value \\
\hline WC & 0.650 & 0.11 & -0.577 & 0.17 \\
\hline SBP & 0.514 & 0.23 & -0.511 & 0.24 \\
\hline DBP & -0.049 & 0.91 & 0.060 & 0.89 \\
\hline FBS & 0.741 & 0.05 & -0.576 & 0.17 \\
\hline HDL & 0.460 & 0.29 & -0.249 & 0.58 \\
\hline TGL & -0.104 & 0.82 & -0.134 & 0.77 \\
\hline Table 7. Correlation between FT4, TSH and Metabolic \\
Syndrome Parameters in Sub-Clinical Hypothyroid \\
Patients \\
\hline
\end{tabular}

( $\mathrm{P}$ valve $>0.05$ not significant at $5 \%$ level)

Correlation coefficient values between FT4, TSH and metabolic parameters are not significant in our study, because of limited number of study subjects and variants are high.

\section{CONCLUSION}

In our study population, we found that presence of thyroid dysfunction in $16.7 \%$ of newly detected metabolic syndrome patients. Prevalence of hypothyroidism is $15.0 \%$ (overt hypothyroidism 3.3\% and sub-clinical hypothyroidism $11.7 \%$ ) in newly detected metabolic syndrome study patients, which is higher than that of thyroid dysfunction in general population. One-sixth of metabolic syndrome patients or every sixth metabolic syndrome had hypothyroidism, either overt or subclinical. Herewith, we recommend routine screening of thyroid dysfunction in all newly detected thyroid dysfunction patients and exclude the presence of thyroid dysfunction, while managing exciting metabolic syndrome patients.

\section{DISCUSSION}

The metabolic syndrome is a cluster of metabolic abnormalities wherein people are obese and have hypertension, high triglyceride level, low high density lipoprotein cholesterol and abnormal fasting glucose levels.(4) People with metabolic syndrome are at high risk for developing cardiovascular disease and type 2 diabetes. Hypothyroidism is associated with lipid abnormalities like high triglycerides and low high density lipoproteins, weight gain, glucose intolerance and hypertension. Thus, hypothyroidism mimics the parameters of metabolic syndrome.

In this study, thyroid dysfunction prevalence is $16.7 \%$ among metabolic syndrome patients. Hypothyroidism is $15 \%$ prevalent in metabolic syndrome patients (overt hypothyroidism $3.3 \%$ and sub-clinical hypothyroidism $11.7 \%$ ). The prevalence of thyroid dysfunction and hypothyroidism in metabolic syndrome patients are higher than the prevalence in normal population, which is $5.9 \%$ for thyroid dysfunction and $4.6 \%$ for hypothyroidism $0.3 \%$ overt and $4.3 \%$ sub-clinical hypothyroidism).(28) This study is consistent with study done by Uzunulu et al, as $16.4 \%$ of metabolic syndrome patients had hypothyroidism in Japan.(10) In this study, prevalence of sub-clinical hyperthyroidism is $1.7 \%$ and there is no overt or clinical hyperthyroidism.

In this study, one-sixth of metabolic syndrome patients or every sixth patient with metabolic syndrome has hypothyroidism. In these hypothyroidism patients, treatment with levothyroxine replacement reverses the symptoms and signs of hypothyroidism, thereby those factors which mimic metabolic syndrome.

It is well known and proven that by treating with levothyroxine replacement in all overt or clinical hypothyroid patients, we can reduce all the metabolic parameters and cardiovascular risk. There is some controversy in treating sub-clinical hypothyroidism patients. $(29,30,31)$

Management of patients' sub-clinical hypothyroidism remain controversial, because the body of scientific evidence available to guide clinical decision is limited. The risk of progression from subclinical hypothyroidism to overt hypothyroid is $2 \%$ - $5 \%$ per year.(32) A meta-analysis report shows that levothyroxine therapy in individuals with subclinical hypothyroidism lowers mean serum total and low density cholesterol concentration significantly and the reduction in serum cholesterol may be larger in individuals with higher pre-treatment cholesterol levels.(33) Another double-blind placebo-controlled trial (Basal Thyroid Study) shows that an important risk reduction of cardiovascular mortality of $9 \%$ - $31 \%$ possible by improvement in low density lipoprotein cholesterol in sub-clinical hypothyroidism patients treated with levothyroxine therapy. $(34,35)$ Surks et al recommends treating sub-clinical hypothyroidism associated with type 2 diabetes and hypertension in his scientific review. As the metabolic syndrome patients have hyperlipidaemia, diabetes, hypertension and increased cardiovascular risk, it looks logical to treat metabolic syndrome patients having subclinical hypothyroidism by levothyroxine replacement therapy. While there appears to be no adverse effects of 
initiating levothyroxine treatment in this setting, inadvertent overtreatment occurs in $14 \%-21 \%$ of levothyroxine treated patients(36) carrying potential risks of osteoporosis and atrial fibrillation when serum TSH falls below $0.1 \mathrm{mU} / \mathrm{L}$. These patients need frequent thyroid function tests to avoid this complication. Latest evidences suggest that Metformin induces a reduction in TSH levels, both in overt and in subclinical hypothyroidism.(37) Since Metformin is the treatment of choice for Metabolic syndrome and as the evidences suggest Metformin may reduce the TSH level, Metformin is the preferred drug for newly detected metabolic syndrome patients with subclinical hypothyroidism.

This study shows that the prevalence of thyroid dysfunction in metabolic syndrome patients is higher than in normal subjects. One sixth of metabolic syndrome patients or every sixth metabolic syndrome had hypothyroidism either overt or subclinical. This finding indicates a need for investigating the presence of Thyroid dysfunction during managing metabolic syndrome patients. As shown in previous evidences, managing these hypothyroid in metabolic syndrome patients are rewarding by improvement in the metabolic parameters and reducing cardiovascular risk.

\section{REFERENCES}

[1] Reaven GM. Banting lecture 1998. Role of insulin resistance in human disease. Diabetes 1988;37(12):1595-607.

[2] Reaven GM. Insulin resistance, cardiovascular disease, and the metabolic syndrome: how well do the emperor's clothes fit? Diabetes Care 2004;27(4):10112.

[3] Grundy SM. Obesity, metabolic syndrome and cardiovascular disease. J Clin Endocrinol Metab 2004;89(6):2595-600.

[4] Eckel RH, Grundy SM, Zimmet PZ. The metabolic syndrome. Lancet 2005;365(9468):1415-28.

[5] Cappola AR, Ladenson PW. Hypothyroidism and atherosclerosis. J Clin Endocrinol Metab 2003;88(6):2438-44.

[6] Hak AE, Pols HA, Visser TJ, et al. Subclinical hypothyroidism is an independent risk factor for atherosclerosis and myocardial infarction in elderly women: the rotterdam study. Ann Intern Med 2000;132(4):270-8.

[7] Klein I, Ojamaa K. Thyroid hormone and the cardiovascular system. N Engl J Med 2001;344(7):5019.

[8] Duntas LH. Thyroid disease and lipids. Thyroid 2002;12(4):287-93.

[9] Dillman WH. Mechanism of action of thyroid hormones. Med Clin North Am 1985;69(5):849-61.

[10] Uzunlulu M, Yorulmaz E, Oguz A. Prevalence of subclinical hypothyroidism in patients with metabolic syndrome. Endocr J 2007;54(1):71-6.

[11] Shrestha S, Das BKL, Baral N, et al. Association of metabolic syndrome and its components with thyroid dysfunction in females. Int J Diab Dev Ctries 2007;27(1):24-6.

[12] Alberti KG, Zimmet PZ. Definition, diagnosis and classification of diabetes mellitus and its complications. Part 1: diagnosis and classification of diabetes mellitus provisional report of a WHO consultation. Diabet Med 1998;15(7):539-53.
[13] Expert Panel on Detection, Evaluation, and Treatment of High Blood Cholesterol in Adults. Executive summary of the third report of the national cholesterol education program (NCEP) expert panel on detection, evaluation, and treatment of high blood cholesterol in adults (Adult Treatment Panel III). JAMA 2001;285(19):2486-97.

[14] Balkau B, Charles MA. Comment on the provisional report from the WHO consultation. European group for the study of insulin resistance. Diabet Med 1999;16(5):442-3.

[15] WHO. Definition, diagnosis and classification of diabetes mellitus 1999.

[16] Grundy SM, Cleeman JI, Daniels SR, et al. Diagnosis and management of the metabolic syndrome: an American heart association/national heart, lung, and blood institute scientific statement. Circulation 2005;112(17):2735-52.

[17] The IDF consensus. Worldwide definition of the metabolic syndrome 2004. www.idf.org

[18] Tan CE, Ma S, Wai D, et al. Can we apply the National Cholesterol Education Program Adult Treatment Panel definition of the metabolic syndrome to Asians? Diabetes Care 2004;27(5):1182-6.

[19] WHO. Western pacific region. Redefining obesity and its treatment. WHO/IASO/IOTF 2000.

[20] Zulewski H, Müller B, Exer P, et al. Estimation of tissue hypothyroidism by a new clinical score: evaluation of patients with various grades of hypothyroidism and controls. J Clin Endocrinol Metab 1997;82(3):771-6.

[21] Polikar R, Burger AG, Scherrer U, et al. The thyroid and the heart. Circulation 1993;87(5):1435-41.

[22] Daese MD. Effect of thyroxin therapy on serum lipoproteins in patients with mild thyroid failure. J Clin Endocrinol Metab 2000;22:153-8.

[23] Dullaart RP, Hoogenberg K, Groener JE, et al. The activity of cholesterol ester transfer protein is decreased in hypothyroidism: a possible contribution to alterations in high-density lipoproteins. Eur J Clin Invest 1990;20(6):581-7.

[24] Roos A, Bakker SJ, Links TP, et al. Thyroid function is associated with components of the metabolic syndrome in euthyroid subjects. J Clin Endocrinol Metab 2007;92(2):491-6.

[25] Bakker SJ, Maaten TJC, Popp-Snijders C, et al. The relationship between thyrotropin and lipoprotein cholesterol is modified by insulin sensitivity in healthy euthyroid subjects. J Clin Endocrinol Metab 2001;86(3):1206-11.

[26] Marina AM, Vagenakis AG, Leonardou AS, et al. Thyroid function in humans with morbid obesity. Thyroid 2006;16(1):73-8.

[27] Gharib H, Tuttle RM, Baskin HJ, et al. Subclinical thyroid dysfunction: a joint statement from the American association of clinical endocrinologists, the American thyroid association, and the endocrine society. J Clin Endocrinol Metab 2005;90(1):581-5.

[28] Hollowell JG, Staehling NW, Flanders WD, et al. Serum TSH, T(4), and thyroid antibodies in the United States population (1988 to 1994): national health and nutrition examination survey (NHANES III). J Clin Endocrinol Metab 2002;87(2):489-99. 
[29] Surks MI, Ortiz E, Daniels GH, et al. Subclinical thyroid disease: scientific review and guidelines for diagnosis and management. JAMA 2004;291(2):228-38.

[30] Col NF, Surks MI, Daniels GH. Subclinical thyroid disease: clinical applications. JAMA 2004;291(2):23943.

[31] Mark D. Effect of thyroxine therapy on lipoproteins in patients with mild thyroid failure. J Clin Endocrinol Metab 2000;85:2993-3001.

[32] Meier C, Staub JJ, Roth CB, et al. TSH-controlled Lthyroxine therapy reduces cholesterol level and clinical symptoms in subclinical hypothyroidism: a double blind, placebo-controlled trial (basel thyroid study). J Clin Endocrinol Metab 2001;86(10):4860-6.

[33] Caraccio N, Ferrannini E, Monzani F. Lipoprotein profile in subclinical hypothyroidism: response to levothyroxine replacement, a randomized placebocontrolled study. J Clin Endocrinol Metab 2002;87(4):1533-8.
[34] Ross DS, Daniels GH, Gouveia D. The use and limitations of a chemiluminescent thyrotropin assay as a single thyroid function test in an out-patient endocrine clinic. J Clin Endocrinol Metab 1990;71(3):764-9.

[35] Parle JV, Franklyn JA, Cross KW, et al. Thyroxine prescription in the community: serum thyroid stimulating hormone level assays as an indicator of undertreatment or overtreatment. Br J Gen Pract 1993;43(368):107-9.

[36] Cappola AR, Fried LP, Arnold AM, et al. Thyroid status, cardiovascular risk, and mortality in older adults. JAMA 2006;295(9):1033-41.

[37] Lupoli R, Di Minno A, Tortora A, et al. Effects of treatment with metformin on TSH levels: a metaanalysis of literature studies. Clin Endocrinol Metab 2014;99(1):E143-8. 